\title{
The Effects of Small Scale Gold Mining on Living Conditions: A Case Study of the West Gonja District of Ghana
}

\author{
Mabel A. Hoedoafia (Corresponding author) \\ Faculty of Economics and Business Administration, Catholic University College of Ghana \\ PO Box 363, Fiapre - Sunyani, Ghana \\ Tel: 233-204-303-445Ｅ-mail: mhoedoafia@yahoo.com
}

\begin{abstract}
Benjamin Spears Ngmekpele Cheabu
Faculty of Public Health and Allied Sciences, Catholic University College of Ghana

PO Box 363, Fiapre - Sunyani, Ghana

Tel: +233-208-716-156 E-mail: bscheabu@gmail.com
\end{abstract}

\begin{abstract}
Vida Korang
Faculty of Economics and Business Administration, Catholic University College of Ghana

PO Box 363, Fiapre - Sunyani, Ghana

Tel: +233-208-158-867 E-mail: vdkorang@googlemail.com
\end{abstract}

Received: December 8, 2013 Accepted: January 16, 2014 Published: March 11, 2014

doi:10.5296/ijssr.v2i1.4701 URL: http://dx.doi.org/10.5296/ijssr.v2i1.4701

\begin{abstract}
In recent times, there has been a surge in small scale mining activities in Ghana which has made significant contributions to the national gold output, foreign exchange earnings, and employment among others. This paper investigated the impact of small scale gold mining on the living conditions of the people of the West Gonja District in the Northern Region of Ghana. The research involved: (a) the determination of gender and generation roles in small
\end{abstract}


scale mining activities; (b) the determination of the effect of mining activities on employment, education, health, agriculture and cost of living of the people in the district and (c) The identification of the areas of interventions that will eradicate the negative effects of small scale gold mining in the district. Data of sampled households in four communities in Damongo was gathered and analyzed. The research methods included; semi structured interviews, validated self-administered questionnaires and observations. Sampling of communities and households was done using a combination of stratified and simple random sampling procedures. The study revealed varied effects with respect to small scale miners and the general community. Small scale mining has contributed positively in improving the lives of the people in the form of employment, revenue generation and meeting health, educational and basic family needs. It also confirmed the associated social, and environmental negative effects of small scale mining. The paper concludes that in the absence of a viable alternative source of economic livelihood, the West Gonja District Assembly should organize small scale miners into groups, assist them to acquire equipment needed for their operations and regularly monitor and control their activities.

Keywords: Small scale gold mining, living conditions, galamsey, gender roles, illegal mining, health, education

\section{Introduction}

For Peiter et al. (2000), small scale mines, as they suggested, are generally those mining operations that are both labour intensive and require low technology. The regularization of Small Scale Mining (SSM) in Ghana in 1989 and the implementation of the Small Scale Gold Mining Law, gave rise to two groups of operators. Those who are legalized (registered) and those who are illegal (unregistered) thus referred to as galamsey - a local term which emanated from the corruption of the phrase "gather them and sell". This has brought corresponding significant socio-economic growth, increased national gold output, increased foreign exchange and employment in Ghana (Hilson, 2002). This notwithstanding, there exist a ubiquity of small scale mines that are unregistered and illegal (Bush, 2009; Hilson, 2009).

For most developing countries, small-scale gold mining is manifested mainly in the form of employment and increased revenues. Although not capital intensive, small-scale gold mining require sufficient manpower and therefore has a significant impact on the livelihoods and employment situation in the developing world, especially in rural areas where there are very few alternatives (Hilson, 2001). Gold mining in Ghana is done on both large and small scale basis. The large scale mining is done legally by bigger mining companies who are mostly from foreign countries. Small scale mining is also done legally or illegally by mostly individuals and groups. The total quantity of gold produced in Ghana per annum is therefore the contributions of both small scale and large scale miners; hence the contribution of small scale mining cannot be overemphasized. The continuous interest in gold and its wealth over the ages in Ghana by both individuals and companies (foreign companies inclusive), have had significant effects on the lives of the people in whose towns and villages mining activities go on. 
Small scale mining is undertaken in both the Northern and Southern parts of Ghana. However, many studies on mining have focused on the south such as Yakovleva (2007) in the Birim North District on the perspectives on female participation in artisanal and small scale mining; the impact of illegal mining on the Ghanaian youth with evidence from the Kwaebibrem District (Owusu \& Dwomoh, 2012); Akabzaa and Darimani(2001) on the Impact of mining sector investments in the Tarkwa region of Ghana; Dartey et al. (2013) on urinary arsenic and mercury levels in artisanal miners in some communities in the Obuasi Municipality; and Small scale gold mining and environmental degradation in Ghana using the Denkyira area as case study (Kessey \& Arko, 2013). According to Dankwa (1999) studies have been conducted in Northern Ghana on poverty, health, education, food security but none has been undertaken to assess the effects of mining activities. Hence, this study focuses on Northern Ghana due to the paucity of peer reviewed studies on small scale mining that have been carried out in that area. Northern Ghana is one of the areas in which gold mining has existed for quite some time. The area is endowed with geological formations that have high mineral holding potential (Darkwa, 1999). By 1996, at least twelve companies had licenses to prospect aside the numerous small scale operators. These companies included Northern Goldfields, Ashanti Goldfields, IAMGOLD, Kenor A. S. International Gold Resources, Cluff Resources and AGEM (Darkwa, 1999). Effective regulatory mechanisms in the view of Darkwa (1999) have been implemented in other areas such as Ashanti, Central and Western regions, yet little or nothing has been done for people affected by small scale gold mining in the Northern Region. The absence of an effective regulatory mechanism has increased the gravity of the negative effects on miners and their communities. Hence, funds provided for infrastructure and social amenities are used to cater for the health needs of the people resulting from the harm caused by uncontrolled hazardous waste and chemicals emanating from the activities of small scale mining. This neglect continues to lead to the deprivation of the area of the necessary social amenities such as schools, hospitals, recreational amenities and infrastructure such as good road networks and pipe borne water.

As a result, Northern Ghana, according to Darkwa (1999, p. 21) "will have a high incidence of the adverse effects of mining if government does not pay due attention to ensuring responsible operations by mining companies and small operators." It is in this regard that this study was undertaken to investigate the effects of small scale gold mining on the living conditions of the people of the West Gonja District in the Northern Region of Ghana.

\section{Literature Review}

Small Scale Gold mining in Ghana is undertaken by individuals and/or groups not exceeding nine or cooperatives of ten people or more on concessions that are less than 25 acres (Agyapong, 1999). Until the recent influx of the Chinese in small scale mining, it was mostly practiced by the indigenes in Ghana. This dates back to the fifth and sixth centuries long before the Europeans came to trade in gold with Ghana (Kesse, 2003). The method used by these miners since time past was surface mining. The operations of the small scale miners do not require a large capital base since rudimentary implements such as pick axes, chisels, shovels and pans are used. That accounts for the large numbers involved in such operations. The situation, however, is different in our contemporary times. Indigenes and their foreign 
counterparts especially the Chinese are in competition. This has led to the inception of heavy duty equipment such as excavators and haulage trucks as witnessed in their operations in Obuasi and Tarkwa. Gold mining on a small scale may either be legal or illegal. It is legal when the small scale miners have the title rights to the mining lands and illegal when they lack such rights. With the enactment of the Small Scale Gold Mining Law in 1989 (PNDCL 218), a lot of small scale gold mining operations have been legalized while some remain illegalized (Agyapong, 1999). Tarkwa, Bogoso, Obuasi, Konongo, Bolgantanga, Bole and Damongo are some of the towns where small scale gold mining take place in Ghana.

The Small Scale mines have grown to provide employment for many inclluding women who are directly or indirectly involved in the mining activities. It is estimated that about 14,000 people are employed by the large mining companies whilst the small scale mining sector popularly known as galamsey, employs about 300,000 people (Hilson \& Nyame, 2006). Yakovleva (2007) examined the issue of growing female participation in the artisanal and small-scale mining (ASM) sector, drawing upon experiences from Birim North District in the Eastern Region of Ghana. It was reported that an estimated $50 \%$ of those employed in ASM were women who contribute directly (i.e. primary engagement in mining operations) and indirectly (i.e. servicing the mine sites). Small scale mining therefore employ and impact the lives of certain categories of persons in their operation areas.

There is an overplus of evidence on the adverse social implications of small scale mining especially in sub-Saharan Africa (Davidson, 1993; UN, 1996; ILO, 1999; Kituk, 2006; Fisher, 2007). The plethora of evidence of waterlogged pits, soil erosion (Hilson, 2002), pollution of food products (Essumang et al., 2007), pollution of rivers and other drinking water sources (Obiri et al., 2010; Paruchin et al., 2010) confirms the latter. The cycle of poverty witnessed in mining areas irrespective of the mining of gold is also worthy of note (See Figure 1 below).

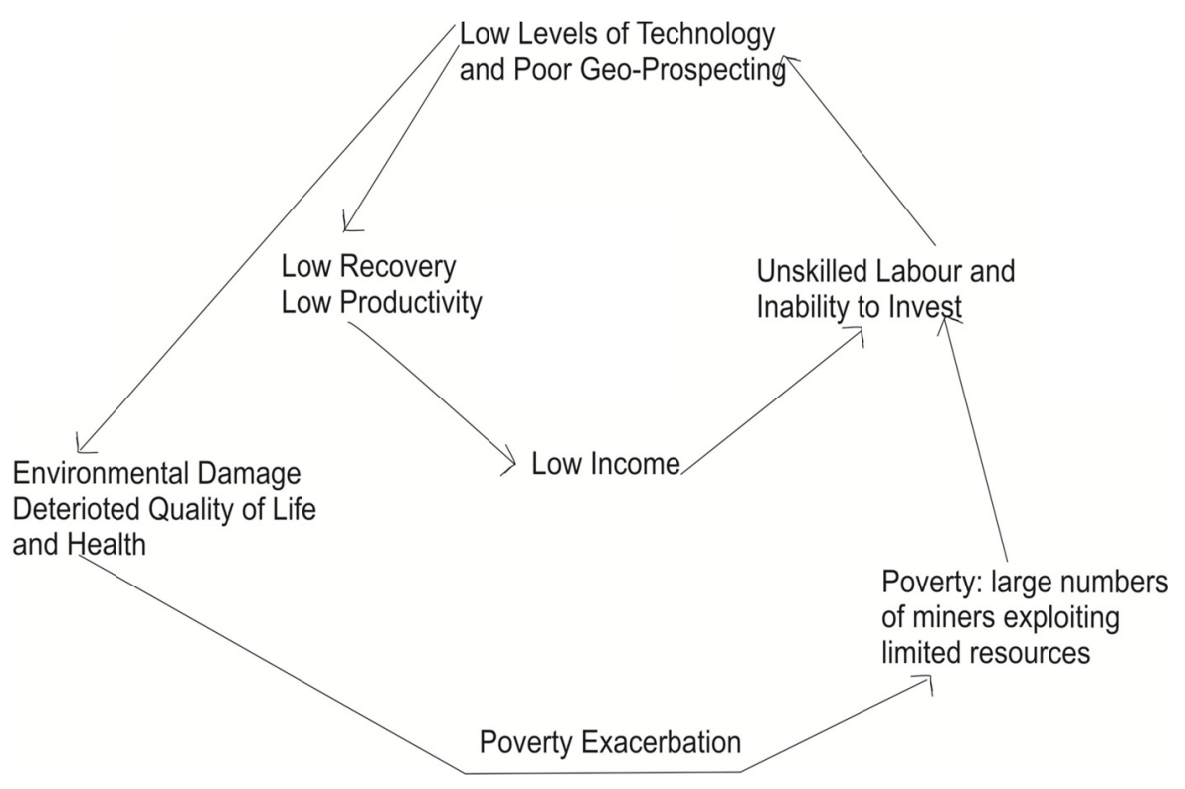

Figure 1. The artisanal mining poverty trap. Source: Reproduced from Hilson and Pardie 


\section{Macrothink}

Banchirigah (2008) reports that despite the externalities of small scale mining activities, community leaders argue that it has been the lifeblood of their communities. She continues that '... alluvial and near surface mineral extraction continues to be a vitall economic activity, and that operators have deep ancestral ties in mining lands. Amidst the arguments and explanations of opportunism and people's desire to get rich offered by policy makers as plausible reasons for the upsurge of small scale mining, poverty has gained the greatest attention and reason' (Barry, 1996; Labonne, 2003). Labonne (2003, p. 131) as cited in Hilson (2003), explains further that "because artisanal mining is largely driven by poverty, it has grown as an economic activity, complementing more traditional forms of rural subsistence earnings'. Similar conclusions were also drawn by the authors of Breaking New Ground (MMSD 2002, p. 314).

The monetary gains from small scale mining activities however, have not substantially improved the livelihood of the general population (see Humphreys, Sachs, \& Stiglitz, 2007). However, there is a justified point of view that small scale mining activities are largely driven by poverty and that "... there is a correlation between the human development index (HDI) position of countries and the proportion of the total workforce involved in ASM" (Hoadley \& Limpitlaw, 2004, p. 1).

\section{Methodology}

\subsection{Study Area}

The West Gonja District is located in the Northern Region of Ghana with Damongo as its capital. According to the 2010 Population Census, the population of the district was 84,727 with about 27,000 living in Damongo. The district shares boundaries in the south with Central Gonja District; Bole and Sawla-Tuna-Kalba Districts in the West, Wa East District in the North West, West Mamprusi in the North, and Tolon Kumbungu District in the East. The District has a total land area of 8,352 sq. $\mathrm{km}$ representing about $12 \%$ of the total land area of the region. It is situated in an old geological area with rocks that are mainly of the voltaian formation with isolated Cambrian rocks, which contain valuable minerals such as gold. Hence, the people in the area engage in small scale gold mining as a complementing source of their economic livelihood.

\subsection{Study Population}

The target population of this paper were the residents of Damongo in the Northern Region of Ghana who were between the ages of 18-65 and have stayed in Damongo for at least five years. The total population of the Damongo Township is 13,115 . Out of this, $51 \%$ were below 18 years. The target population was therefore 6,426 which represent $49 \%$ of the total population. $60 \%$ of the target population were farmers who form the majority of the population while the lowest are students who constitute $1 \%$ of the population (General Profile of West Gonja District, 2005). 


\subsection{Data Collection, Recruitment of Participants and Analysis}

Primary data was collected from 65 households in four communities in Damongo namely Ngbaripe, Zongo, Attributo and Langbonto using validated and assisted questionnaires. The questionnaire was pre-tested randomly among 10 households before administering them to ensure the validity and reliability of the data gathered. Primary data is the first hand information collected from respondents, which included socio-economic characteristics of respondents such as occupation, educational level and age structure as well as soliciting information on what respondents believed where the effects of small scale gold mining on their living conditions. The number of household was limited to 65 due to resource constraints in terms of finance, availability of research assistants, inadequate time and respondents' willingness to participate in the study. The respondents were engaged in different occupations dominant in Damongo. These are farmers, traders, small scale miners, professionals, students and others. A stratified random sampling by occupation was used in gathering the primary data. The data was analyzed with the Statistical Package for the Social Sciences (SPSS) Version 21.0 and Microsoft Excel tools using graphs and charts. Finally the data was analyzed based on the information from both the general public and small scale miners.

The qualitative aspect of the study employed semi structured interviews. Semi structured interviews are credited as appropriate to the collection of data on a topic that lacks previous studies on that study area. Here, the researcher uses a predetermined set of open ended and yet flexible questions which allow the interviewer to diverge from the guide to pursue other details with respect to the study (Drever, 1995). Based on the above premise, a convenience sample of four respondents were drawn from each of the four suburbs of Damongo (Ngbaripe, Zongo, Attributo and Langbonto) to probe further the effects of ASM. Potential participants were briefed of the nature of the study and after an agreement to participate; they were invited at the time and place of their convenience for the interview. Many of these interviews took place in their homes and workplaces. Content analysis was then employed to analyze interview responses by identifying emerging themes.

\section{Results and Discussions}

In assessing the effects of small scale gold mining in Damongo, both positive and negative effects were identified. The effects were analyzed using key socioeconomic indicators as agriculture, education, health, employment and living conditions of both small scale miners and the general community. The contribution to employment was further analyzed on the basis of the generation of gender roles and finally the contribution of small scale mining activities to social vices. The contributions of small scale mining to agriculture have been in the form of increased farm acreage for farmers who have engaged in small scale mining. Thus, their revenues from the mining activities were invested to increase the number of acres they farm resulting in an increased farm produce or increased harvest. According to the study, $52 \%$ of farmers who engaged in small scale gold mining have increased the size of their farms (See Figure 2 below). 


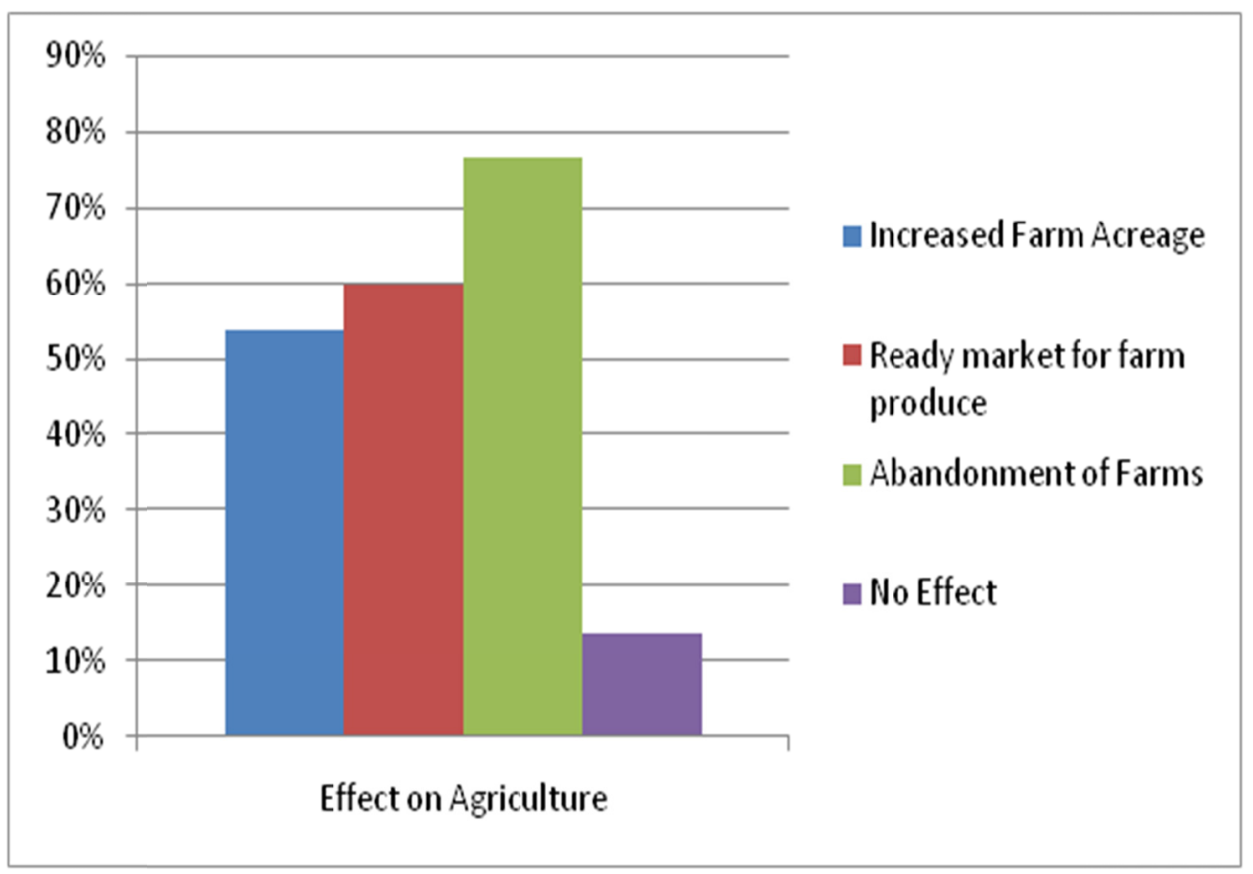

Figure 2. Effects of small scale gold mning on agriuclture

The influx of people from neighbouring villages to Damongo contributed immensely to agriculture; it provided a ready market for farm products. However, $80 \%$ of the respondents asserted that small scale mining have had a negative impact on agriculture as farmers of food crops have abandoned their farms for the quick and high returns associated with small scale mining. Therefore the few farmers are adopting unnatural methods of farming and the use of chemicals which they believe is harmful to the environment and the foods produced. As a result of the latter, there have been claims of the shortage of food supply in the town leading to an astronomical increase in prices of agricultural produce and a high cost of living among the town folks.

The contribution of small scale mining to employment has been significantly high as compared to education and health. About $83 \%$ of the respondents as shown in Figure 3 concerted that, most of the illiterate youth in the area have taken up small scale mining as a source of their economic livelihood whilst others especially the women and girls are engaged in petty trading of goods demanded highly by the miners. Small scale mining has therefore helped to reduce the rate of unemployment [corroborating the findings of Kessey \& Arko, 2013] in the area as well as improvement in the lives of the average people. In terms of education and health, the negative effects outweigh the positive effects. $35 \%$ of respondents (see Figure 3 below) reported that their proceeds from SSM activities have enabled them to send their children to school and are also as well as being able to provide their school needs and other basic needs of other family members. The general public adds that, the presence of small scale gold mining in the town allows their wards to take care of themselves thus, meeting their school and other needs. On the other hand, $38 \%$ of respondents reported that some school going children have dropped out of school (see Figure 3 below), This in their opinion is due to the fact that parents have withdrawn their children from school to help them 


\section{$\triangle$ Macrothink}

in the mining sites while some primary children and even senior secondary school students have dropped out of school to work as small scale miners. According to them, absenteeism and truancy in schools is also high since parents leave their homes for the mining sites and thus, cannot monitor their children who go to school: an endorsement of the findings of Owusu and Dwomoh (2012). Consequently, such children withdraw from school. This leads to increase in the rate of school dropouts in the community and increase in the number of illiterate (uneducated) population. This, without doubt, has an adverse negative effect on their future wellbeing.

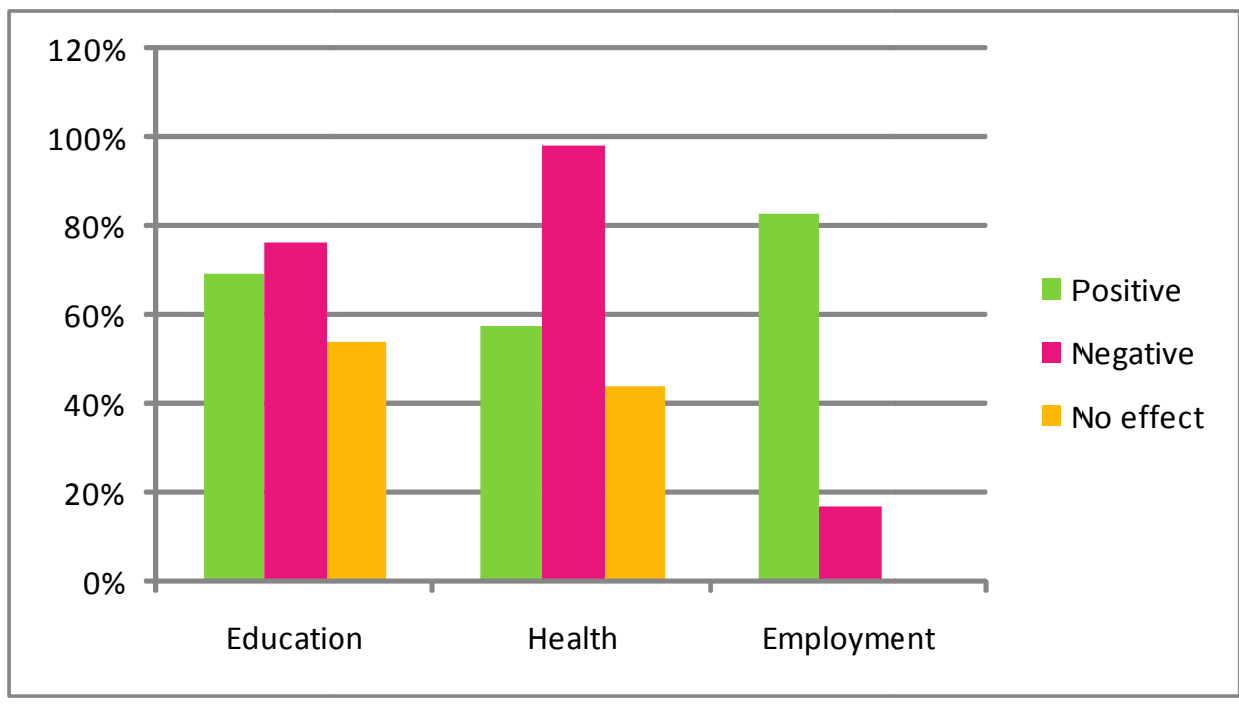

Figure 3. Effects of small scale gold mining on key socio-economic indicators

On health, the case was no different from that of the education sector. In Figure 3 above, 49\% of respondents as compared to $20 \%$ agreed to the fact that, the health status of the small scale miners (SSM) and the community has deteriorated due to mercury contamination, affirming the well known fact that mercury poses a serious threat to human health (Hilson, 2002) and the findings of (Lacerda\&Marins, 1997; Peter van Straaten, 2000; Malm, 1998; Stode, Jaegl\&Selin, 2009) that mercury emissions through small scale mining exposes miners and their communities to severe health risks. There has been the occurrence of diseases such as cough, reddening of eyes, heart and lung diseases, catarrh and hearing problems due to the blasting, vibration and noise associated with mining activities. The lives of the miners are also in danger as the tools and methods used in the mining activities expose them to a high risk of injury.

The resultant effects of SSM were also evidenced in the growing increase in social vices such as prostitution leading to an increase in HIV/AIDS confirming the findings of Banchirigah (2008). Other social vices included robbery, smoking and drunkenness as shown in Figure 4 below, especially among the youth. Some women have also taken to commercial sexual activities to earn a living due to the high demand for sex by the small scalle miners as a form of entertainment after their hard day's work as indicated by the following response: "my 
sister, we all need to survive and to help our families, so if I have such an opportunity to entertain my own people who can pay, why not? ... as for me that is fine, they pay good money ooo" (Interview: Female, Ngbaripe)

Not only is prostitution a problem, but also most of the SSM have taken to smoking especially marijuana, which they believe gives them the needed energy required to work effectively and to sustain them in their labour intensive job:

"I must be frank with you, 'wee' (local jargon for marijuana) gives me extra strength and almost all my brothers can confirm that ... many times as we work we smoke it or before we go into the pit we do our thing." (Interview: Male, Small - scale miner, Langbonto).

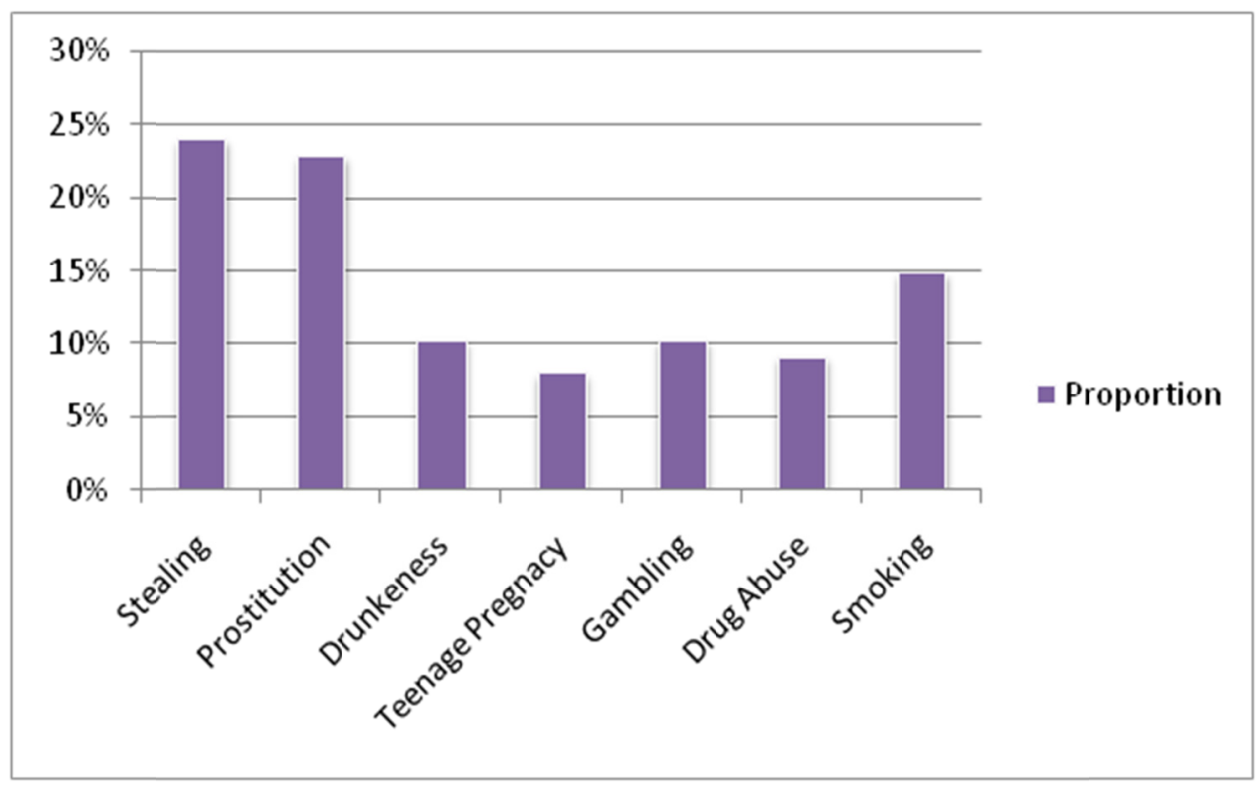

Figure 4. Effects of small scale gold mining on social vicies

Furthermore, stealing especially of domestic animals has become prevalent according to $24 \%$ of the respondents (see Figure 4 above). In their view, the miners highly demand domestic animals for merry making. Hence some youth have capitalized on that to steal such animals and sell at higher prices to the miners. One participant commented:

"Hmm, my daughter, my livestock have known no peace, especially, my goats and sheep since this 'galamsey' thing started ...., my relatives and friends in Attributo have also complained severally of their lost livestock. We just don't know what to do ... parties every weekends ... aahhh my goats." (Interview: Female, Zongo)

Generally, the lives of small scale miners have greatly improved (see Figure 5 below). All of them acknowledged that their jobs and earnings have enabled them to provide three square meals for their families as well as taking care of other needs of the family such as: provision of books and other learning materials) for their children and the payment of school fees; registering to be part of the national health insurance scheme and having the ability to pay 
any hospital bills not covered by the health insurance; acquiring nice clothes for themselves and their families and enjoying some leisure or entertainment. Some have also been able to build their own houses and own taxi cabs. This allows for an easy transporting of people within the district.

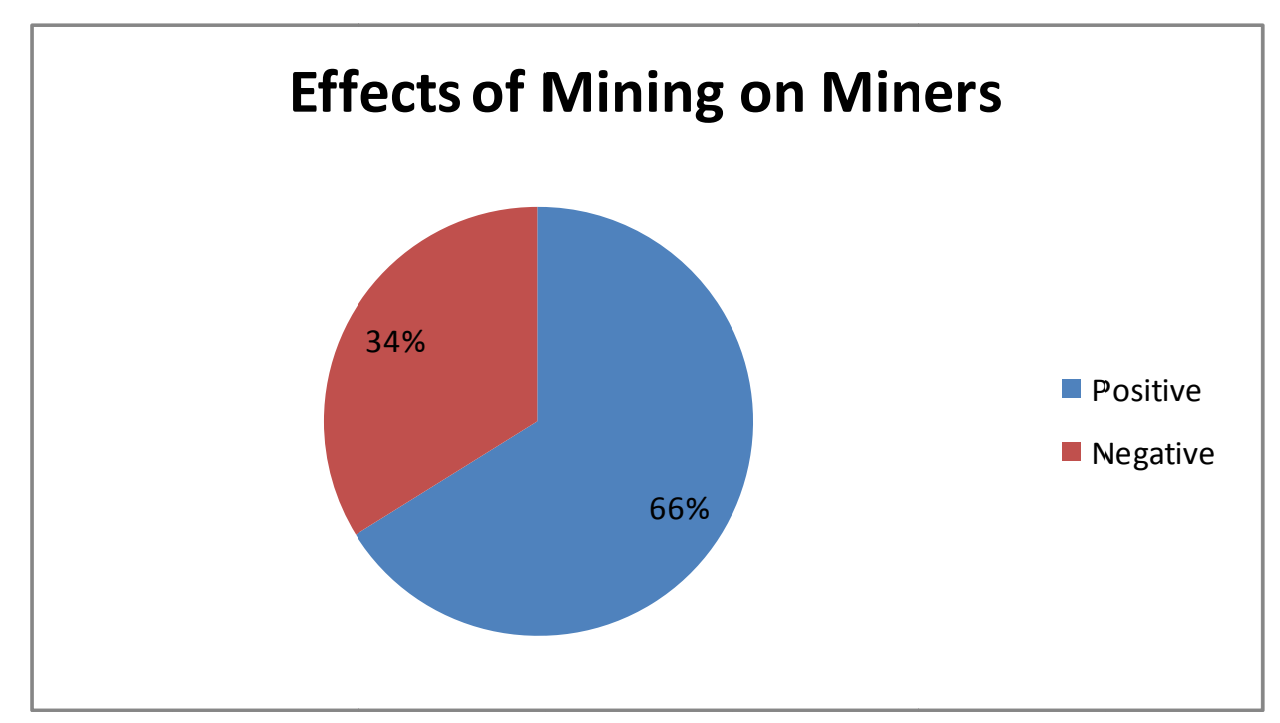

Figure 5. Effects of Small Scale Gold mining on the Living Conditions of Miners

Although the lives of SSM have significantly improved, on the average, the conditions of living have been high for the other members of the community who are not involved directly or indirectly in mining activities. The area has witnessed an increasing rise in the prices of rent, goods and especially food and dairy products. According to $74 \%$ of the respondents as shown in Figure 6 below, the introduction of mining in the town has resulted in many farmers abandoning their farms for the quick and high income generated by the mining sector. Thus, food supply is inadequate for the growing population leading to higher food prices hence a high cost of living.

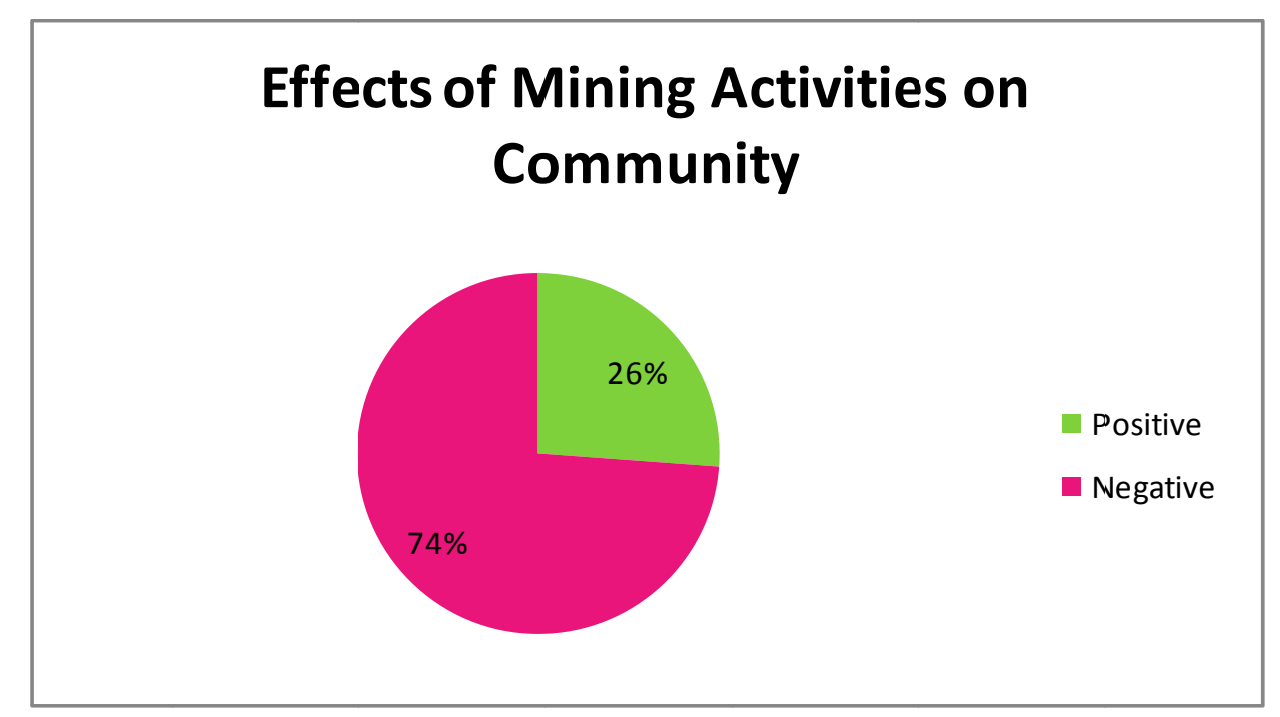

Figure 6. Effects of Small Scale Gold Mining on the Living Conditions of the Community 
Some interviewees also reported that, miners who earned higher wages offer higher prices for agricultural produce; thereby making it difficult for the ordinary people to afford such prices:

"....these days you cannot just bargain for anything when you go to the market. These 'money guys'(small scale miners) show off ... see, what we used to buy for GH 2 can no more be bought, because these boys offer more to the sellers. (Interview: Male, Attributo)

This notwithstanding, about $26 \%$ of respondents(see Figure 6 above) indicated that small scale mining has increased the number of the employed population thereby reducing the dependency rate on the few who were employed. Moreover, farmers earn higher incomes from the sale of their farm produce. The tax base of the district has also been widened as the small scale miners pay GH5 per month to the district assembly.

\section{Conclusion}

Having examined the effects of small scale gold mining on the people of Damongo in the Northern Region of Ghana, the primary data revealed that small scale golld mining benefited the people of Damongo in the form of employment, revenue generation used to cater for educational, health and basic family needs as well as increase in farm size which results in high farm produce and the generation of employment roles for women. The negative effects, however, were in the emerging high cost of living, increased social vices especially prostitution, deteriorating health, increase in school dropout rates, abandonment of farms and loss of farm land. These effects confirm the results of the documentary search which revealed the various importance of small scale gold mining activities as employment, revenue to government and the miners, foreign exchange, rural transformation, raw materials for jewelry industry and social vices. The major problems of small scale gold mining were classified as social and environmental. The social problems identified included high cost of living, increased school dropout rate, health problems, prostitution and drug abuse, displacement of people from their settlements and loss of land. The environmental problems included air pollution, waste and chemical pollution, deforestation and land degradation.

As part of efforts to help the situation, respondents suggested that miners be encouraged to form associations to provide for them, among others, an avenue to edlucate them on the dangers and safety measures associated with their work. In the absence of a viable alternative source of economic livelihood for small scale miners, the paper concludes that the West Gonja District Assembly should organize small scale miners into groups, assist them to acquire equipment needed for their operations and regularly monitor and control their activities. For further research, the paper proposes a detailed study on the role and impact of education on the dangers and safety measures of small scale gold mining in the area.

\section{References}

Agyapong, K. (1999). Small Scale Mining in Ghana. An environmental Magazine of Friends of the Earth Ghana, No. 12

Akabzaa, T., \& Darimani, A. (2001). Impact of Mining Sector Investment in Ghana: a study of the Tarkwa Mining Region. SAPRI report. 


\section{MInstitute Macrothink $_{\text {Int }}$}

International Journal of Social Science Research

ISSN 2327-5510

2014, Vol. 2, No. 1

Banchirigah, S. M. (2008). Challenges with eradicating illegal mining in Ghana: A Perspective from the grassroots. Resources Policy, 33, 29-38. http://dx.doi.org/10.1016/j.resourpol.2007.11.001

Barry, M. (1996). Regularizing informal mining. A summary of the proceedings of the International Roundtable on Artisanal Mining. Washington, DC: World Bank, Industry and Energy Department

Bush, R. (2009). Soon there will be no-one left to take the corpses to the morgue: Accumulation and abjection in Ghana's mining communities. Resources Policy, 34, 57-63. http://dx.doi.org/10.1016/j.resourpol.2008.02.002

Dankwa, Y. (1999). Mining: Northern Ghana at Risk. Environmental Magazine of Friends of the Earth Ghana, No. 12.

Dartey, E., Sarpong K., Darko, G., \& Acheampong-Marfo, M. (2013). Urinary arsenic and mercury levels in artisanal miners in some communities in the Obuasi Municipality of Ghana. Journal of Environmental chemistry and Ecotoxicology, 5(5), 113-118.

Davidson, J. (1993). The transformation and successful development of small-scale mining enterprises in developing countries. Natural Resources Forum, 17(4), 315-326. http://dx.doi.org/10.1111/j.1477-8947.1993.tb00192.x

Drever, E. (1995). Using Semi-structured Interviews in Small-scale Research. Edinburgh: Scottish Council for Research in Education

Essumang, D. K., Dodoo, D. K., Obiri, S., \& Yaney, J. Y. (2007). Arsenic, Cadmium and Mercury in Cocoyam (Xanthosomasagititolium) and Watercocoyam (Colocasiaesculenta) in Tarkwa, a Mining Community. Bull. Env. Conta. Tox., 79, 377-379. http://dx.doi.org/10.1007/s00128-007-9244-1

Fisher, E. (2007). Occupying the margins: labour integration and social exclusion in artisanal mining in Tanzania. Development and Change, 38(4), 735-760. http://dx.doi.org/10.1111/j.1467-7660.2007.00431.x

Hilson, G. (2001). A Contextual Review of the Ghanaian Small-Scale Mining Industry. Mining, Minerals and Sustainable Development Working Paper No. 76.

Hilson, G. (2002a). The Environmental Impact of Small-Scale Gold mining in Ghana: Identifying Problems and Solutions. The Geographical Journal, 168(1), 57-72.

Hilson, G. (2002b). Small Scale Mining and its Socio-economic Impact in Developing Countries. Natural Resources Forum 26, 3-13. http://dx.doi.org/10.1111/1477-8947.00002

Hilson, G. (2009). Small-scale mining, poverty \& economic development in Sub-saharan Arica: An overview. Resources Policy, 34, 1-5. http://dx.doi.org/10.1016/j.resourpol.2008.12.001

Hilson, G., \& Nyame, F. (2006). Gold mining in Ghana's forest reserves: a report on the current debate. Area, 38, 175-185. http://dx.doi.org/10.1111/j.1475-4762.2006.00670.x 
Hilson, G., \& Pardie, S. (2006). Mercury: an agent of poverty in Ghana's small-scale gold mining industry? Resources Policy, 31(2), 106-116. http://dx.doi.org/10.1016/j.resourpol.2006.09.001

Hoadley, M., \& Limpitlaw, D. (2004). The Artisanal and Small Scale Mining Sector \& Sustainable Livelihoods. A paper presented at the Mintek Small Scale Mining Conference 2004, 9 September, Nasrec, Johannesburg, Book of Proceedings (pp. 1-9).

Humphreys, M., Sachs, J.D., \& Stiglitz, J.E. (2007).Escaping the Resource Curse. New York, NY: Columbia University Press.

International Labour Organization (ILO). (1999). Social and labour issues in small-scale mines. Report for discussion at the Tripartite Meeting on Social and Labour Issues in Small-scale Mines, International Labour Organization, Sectoral Activities Programme, International Labour Office, Geneva.

Kesse, G. O. (2003). Suggestions for Enhancing the Value of Ghana Mineral Resources. In Management of Ghana's Natural Resources: The Proceedings of the Ghana Academy of Arts and Sciences 1995. Vol. xxxiv, 1995. Accra: Ghana Universities Press.

Kessey, D. K. \& Arko, B. (2013). Small Scale Gold mining and environmental degradation in Ghana: Issues of mining policy implementation and challenges. Journal of Studies in Social Sciences, 5(1), 12-30.

Kitula, A. G. N. (2006). The environmental and socio-economic impacts of mining on local livelihoods in Tanzania: a case study of Geita District. Journal of Cleaner Production, 14(3-4), 405-414. http://dx.doi.org/10.1016/j.jclepro.2004.01.012

Labonne, B. (2003). Seminar on artisanal and small-scale mining in Africa: identifying best practices and building the sustainable livelihoods of communities. The Socio-Economic Impacts of Artisanal and Small-Scale Mining in Developing Countries. AA Balkema, The Netherlands, 131-150. http://dx.doi.org/10.1201/9780203971284.ch9

Lacerda, L. D., \& Marins, R. V. (1997). Anthropogenic Mercury Emissions to the Atmosphere in Brazil: The Impact of gold Mining. Journal of Geochemical Exploration, 58(2-3), 223-229. http://dx.doi.org/10.1016/S0375-6742(96)00068-4

Malm, O. (1998). Gold Mining as a source of Mercury Exposure in the Brazilian Amazon. Environmental Research, Section A, 77, 73-78. http://dx.doi.org/10.1006/enrs.1998.3828

Mining, Minerals and Sustainability Development (MMSD, 2002). The Report of the Mining, Minerals and Sustainable Development Project. London: Earthscan Publications Limited.

Ministry of Food and Agriculture. (n.d.). West Gonja. Retrieved May 11, 2013, from http://mofa.gov.gh/site/?page_id=1623

Obiri, S., Dodoo, D. K., Essumang, D. K., \& Armah, F. A. (2010).Cancer and non-cancer risk assessment from exposure to arsenic, copper and cadmium in borehole, tap and surface water 
in the Obuasi municipality, Ghana. Hum. Ecol. Risk. Assess., 16(3), 651-665. http://dx.doi.org/10.1080/10807031003788907

Owusu, E. E., \& Dwomoh, G. (2012). The Impact of Illegal Mining on the Ghanaian Youth: Evidence from Kwaebiribrem District in Ghana. Research on Humanities and Social Sciences, 2(6), 86-93.

Paruchuri, Y., Siuniak, A., Johnson, N., Levin, E., Mitchell, K., Goodrich, J. M., ... Basu, N. (2010). Occupational and environmental mercury exposure among small-sicale gold miners in the Talensi-Nabdam District of Ghana's Upper East region. Sci. Total Env., 408, 6079-6085. http://dx.doi.org/10.1016/j.scitotenv.2010.08.022

Peiter, C., Villas-Boas, R. C., \&Shinya, W. (2000). The stone forum: implementing a consensus building methodology to address impacts associated with small mining and quarry operations. Natural Resources $\quad$ Forum, $\quad 24(1), \quad$ 1-9. http://dx.doi.org/10.1111/j.1477-8947.2000.tb00924.x

Strode, S., Jaegl, L. \&Selin, E. N. (2009). Impact of Mercury Emissions from historic gold and silver mining: Global modeling. Atmospheric Environment, 23(12), 2012-2017. http://dx.doi.org/10.1016/j.atmosenv.2009.01.006

United Nations (UN). (1996). Recent Developments in Small-Scale Mining. Economic and Social Council, United Nations, New York.

van Straaten, P. (2000). Mercury Contamination associated with Small-scale Gold Mining in Tanzania and Zimbabwe. Science of the Total Environment, 259(1-3), 105-113. http://dx.doi.org/10.1016/S0048-9697(00)00553-2

Yakovleva, N. (2007). Perspectives on female participation in artisanal and small scale mining: A case study of the Birim North District of Ghana. Resources Policy, 32, 29-41. http://dx.doi.org/10.1016/j.resourpol.2007.03.002

Yelpaala, K. (2004). Mining, Sustainable Development and Health in Ghana. The Akwatia Case-Study.

\section{Copyright Disclaimer}

Copyright reserved by the author(s).

This article is an open-access article distributed under the terms and conditions of the CreativeCommons Attribution license (http://creativecommons.org/licenses/by/3.0/). 